\title{
Inducible Protective Processes in Animal Systems XIII: Comparative Analysis of Induction of Adaptive Response by EMS and MMS in Ehrlich Ascites Carcinoma Cells
}

\author{
Periyapatna Vishwaprakash Mahadimane and Venkateshaiah Vasudev \\ Department of Studies in Bioscience, Post-Graduate Centre, University of Mysore, Hemagangotri, Hassan, Karnataka 573220, India \\ Correspondence should be addressed to Venkateshaiah Vasudev; profvvasudev@gmail.com
}

Received 25 January 2014; Revised 9 May 2014; Accepted 12 May 2014; Published 4 June 2014

Academic Editor: Nicolaas A. Franken

Copyright (C) 2014 P. V. Mahadimane and V. Vasudev. This is an open access article distributed under the Creative Commons Attribution License, which permits unrestricted use, distribution, and reproduction in any medium, provided the original work is properly cited.

In order to investigate the presence of adaptive response in cancerous cells, two monofunctional alkylating agents, namely, ethyl methanesulfonate (EMS) and methyl methanesulfonate (MMS), were employed to treat Ehrlich ascites carcinoma (EAC) cells in vivo. Conditioning dose of $80 \mathrm{mg} / \mathrm{kg}$ body weight of EMS or $50 \mathrm{mg} / \mathrm{kg}$ body weight of MMS and challenging dose of $240 \mathrm{mg} / \mathrm{kg}$ body weight of EMS or $150 \mathrm{mg} / \mathrm{kg}$ body weight of MMS were selected by pilot toxicity studies. Conditioned EAC cells when challenged after $8 \mathrm{~h}$ time lag resulted in significant reduction in chromosomal aberrations compared to challenging dose of respective agents. As has been proved in earlier studies with normal organisms, even in cancerous cells (EAC), there is presence of adaptive response to methylating and ethylating agents. Furthermore, it is also interesting to note in the present studies that the methylating agent, MMS, is a stronger inducer of the adaptive response than the ethylating agent, EMS.

\section{Introduction}

An important and essential characteristic of organisms is their ability to survive in face of repeated exposure to different physical and chemical genotoxic agents. Adaptive response is one of many defense mechanisms that have evolved to minimize genotoxic damages. In 1977, Samson and Cairns [1] demonstrated this phenomenon in E. coli and they showed that a response was induced by a low level of MNNG that enabled cells both to survive and to be less mutated by subsequent high toxic dose of MNNG than control cultures. After this discovery, extensive work has been done by using prokaryotes and in vitro and in vivo eukaryotes [2-11] including in vitro human lymphocytes [12-20]. Reports are available on the existence of such phenomenon even in higher plants [21-23]. Our laboratory also reported cytogenetic adaptive response in in vivo animal systems such as grasshopper Poecilocerus pictus [24-27] and mouse [28-32].

From several recent studies it is also interesting to note the presence of adaptive response not only in normal cells but also in cancer cells. Scrutiny of reports has demonstrated the protection against radiations in human malignant melanoma, epidermoid laryngeal carcinoma, ovarian carcinoma, myeloma, fibrosarcoma, glioblastoma, and epithelial carcinoma [33-37], but only a very few reports are available in chemically induced adaptive response [38-40]. Contrary to these results, Park et al. [41] using mouse papilloma and lymphoma, Schaffer et al. [42] using human bladder carcinoma, Jiang et al. [43] using two leukemia cell lines (erythroleukemia, promyelocytic leukemia) and two solid tumor cell lines (lung carcinoma and glioma), Sowa et al. [44] using colon carcinoma, and Wang et al. [45] using gastric cancer cells have clearly showed the absence of the adaptive response. Thus, there are conflicting reports on the adaptive response in cancerous cell. Further, as far as the authors are aware, in almost all the studies in cancer cells, the adaptive response has been assessed on the basis of cell survival. No attempt has been made by using cytogenetic assay to determine the adaptive response on one hand and, on the other hand, there are also no sufficient reports on adaptive 
response induced by chemical agents in cancerous cells. This has prompted us to study the influence of alkylating agents on adaptive response in cancerous cells and results are presented here.

\section{Materials and Methods}

2.1. Chemicals. Alkylating agents, methyl methanesulfonate (MMS) (CAS number 66-27-3), and ethyl methanesulfonate (EMS) (CAS number 62-50-0) were obtained from Sigma Co., St. Louis, MO, USA, and colchicine (CAS number 6486-8) was obtained from Himedia, Pvt. Ltd., Mumbai, India. Giemsa stain and other chemicals of analytical grade were commercially available. EMS and MMS were dissolved in $0.9 \% \mathrm{NaCl}$ to obtain the required concentrations. Freshly prepared solutions of these agents were used each time. The conditioning and challenging doses of EMS (80 and $240 \mathrm{mg} / \mathrm{kg}$ body weight) and MMS (50 and $150 \mathrm{mg} / \mathrm{kg}$ body weight) were selected from the earlier experiments [28, 29]. Even though these were selected from treated normal animals, the effect of these along with the range (namely, $25-160 \mathrm{mg} / \mathrm{kg}$ body weight of MMS and 50-300 mg/kg body weight of EMS) of doses was analyzed in EAC cells by preliminary pilot toxicity studies.

2.2. Animals. Male Swiss albino mice weighing 25-30 g of 68 weeks old were used and housed in polypropylene cages which were provided with standard feed pellets and water ad libitum under $12 \mathrm{~h}$ of light/dark cycle. Study was approved by the Institutional Animal Ethical Committee according to the institutional guidelines and the national animal welfare regulations.

2.3. Tumor Cells. Animals with the Ehrlich ascites carcinoma (EAC) cells were initially obtained from Department of Applied Zoology, Mangalore University, Mangalore, India, and EAC cells were maintained by weekly intraperitoneal (i.p.) inoculation of $10^{6}$ cells/mouse.

2.4. Treatment Schedule. Each animal was inoculated with $0.2 \mathrm{~mL}$ of saline containing $1 \times 10^{6}$ EAC cells and this day was taken as zero day. On the tenth day after inoculation, $0.5 \mathrm{~mL}$ of saline containing conditioning or challenging doses of EMS or MMS or $0.5 \mathrm{~mL}$ of saline only was injected i.p. into animals. For combined treatment, $8 \mathrm{~h}$ time lag (TL) between conditioning and challenging doses was selected from the previous experiments by the authors [28, 29], who have shown that an $8 \mathrm{~h}$ time lag has offered the maximum protection with respect to chromosomal aberrations in mouse bone marrow cells compared to other time lags. $24 \mathrm{~h}, 48 \mathrm{~h}$, and $72 \mathrm{~h}$ recovery times have been employed for all groups for chromosome analysis.

2.5. Chromosome Analysis. Each animal received $0.5 \mathrm{~mL}$ of $0.05 \%$ colchicine by i.p. injection 90 minutes prior to the removal of ascites. $0.1 \mathrm{~mL}$ of ascitic fluid was removed at $24 \mathrm{~h}, 48 \mathrm{~h}$, and $72 \mathrm{~h}$ recovery times. This was processed and slides were prepared by modified method of Evans et al.
[46]. In brief, $0.1 \mathrm{~mL}$ ascitic fluid was added to $0.4 \mathrm{~mL}$ of $0.3 \% \mathrm{NaCl}$ and this was incubated at $37^{\circ} \mathrm{C}$ for 45 minutes. After incubation, the mixture was centrifuged at $1000 \mathrm{rpm}$ for 10 minutes and the supernatant was discarded. To the pellet, $5 \mathrm{~mL}$ of fixative $(3: 1 \mathrm{v} / \mathrm{v}$ of ethanol : acetic acid) was added and mixed intensively to avoid clumping of cells. The tubes were kept at $4^{\circ} \mathrm{C}$ for 30 minutes and then centrifuged at $2000 \mathrm{rpm}$ for 5 minutes. The pellet was processed thrice as above. Finally the pellet was resuspended in $0.5 \mathrm{~mL}$ of fixative, dropped on to clean, nongreasy, prechilled slides, and heat fixed. Coded Giemsa stained slides were screened for presence of chromosomal aberrations such as chromatid breaks, exchanges, triradials, intrachromatid deletion, isochromatid deletion, dicentrics, rings, and minutes and tabulated. In each treatment group, a minimum of 300 wellspread, nonoverlapping metaphase plates was scored and a minimum of three experiments was conducted for all recovery times.

2.6. Statistical Analysis. The data obtained from the experiments were subjected to statistical analysis to determine the significance level between the control and treatment groups. The difference that exists among the treatment groups was analyzed using the Duncan multiple comparison post hoc test using the SPSS software (version 17.0). Breaks/cell was calculated as per the method of Savage [47].

\section{Results and Discussion}

Alkylating agents are one of the extensively used drugs for cancer chemotherapy for long-term treatment [48-50]. Among these agents, monofunctional methylating and ethylating agents are prominent in these days of cancer protection $[51,52]$ because of their clastogenic and mutagenic potency in varied genetic systems [53-58]. Clastogenic effects of both EMS and MMS have been well documented even in cancerous cells [59-61]. For the first time, using chromosomal analysis, Mahadimane and Vasudev [62] showed induction of aberrations in EAC cells by MMS and these studies with that of Lettré et al. [63] have suggested exploiting this cell line for clastogenic adaptive response.

S-dependent nature of EMS and MMS by inducing mostly chromatid type of aberrations in EAC cells (Tables 1,2 , and 3) corresponds to similar effects of these agents in different test systems $[64,65]$. This is also true with reference to the induction of chromosomal aberrations in EAC cells irrespective of different recovery times (Tables 13 ). It is also clear from the these tables that even though low dose of EMS ( $80 \mathrm{mg} / \mathrm{kg}$ body weight) produces a significant level of aberrations compared to controls, a dose as less as $50 \mathrm{mg} / \mathrm{kg}$ body weight of MMS is sufficient to induce still more aberrations compared to EMS. This is also true with challenging dose in EAC cells where the yield of breaks/cell after exposing to EMS and MMS was $0.91 \pm 0.04$ and $1.35 \pm$ 0.06 , respectively, at $24 \mathrm{~h}$ RT (Figures 1 and 2 ). These values are highly significant compared to control $(P<0.01)$. Similarly Rao and Natarajan [64] using Vicia faba, Vogel and Natarajan [65] using Drosophila, Riaz Mahmood et al. [29] 


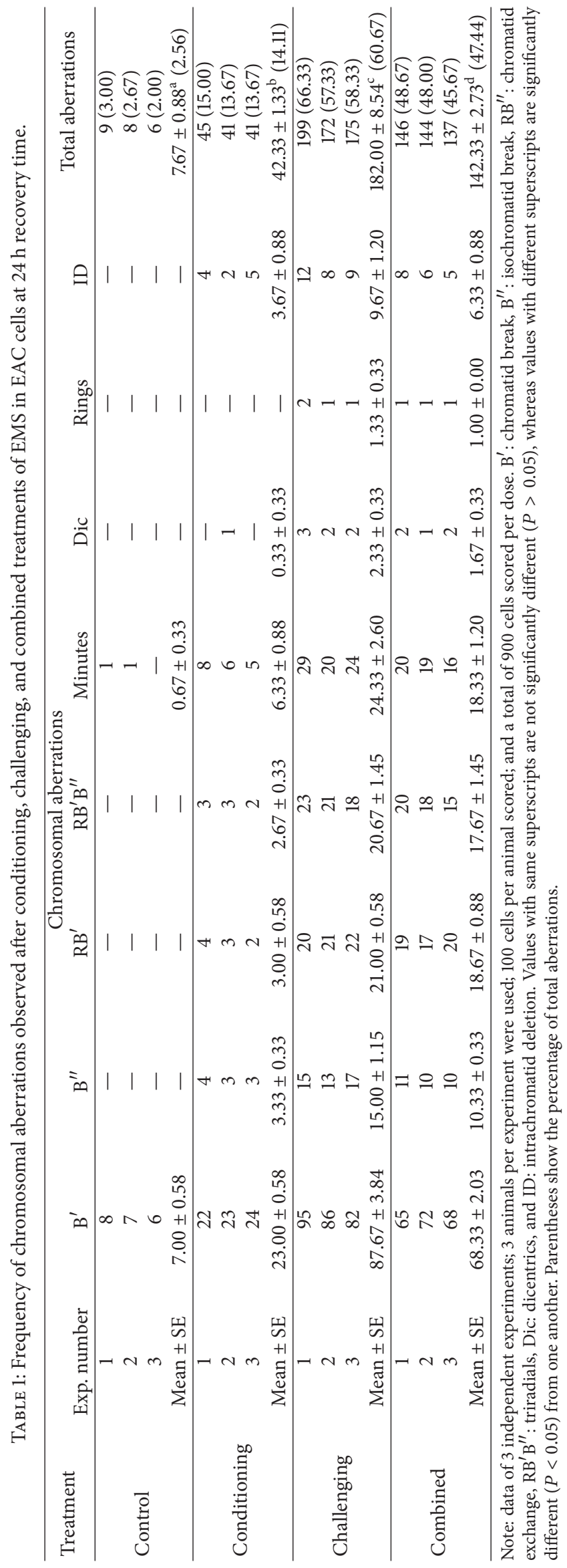


TABLE 2: Frequency of chromosomal aberrations observed after conditioning, challenging, and combined treatments of EMS in EAC cells at $48 \mathrm{~h}$ and $72 \mathrm{~h}$ recovery times.

\begin{tabular}{|c|c|c|c|c|}
\hline \multirow{2}{*}{ Recovery time (h) } & \multirow{2}{*}{ Treatment } & \multicolumn{2}{|c|}{ Chromosomal aberrations } & \multirow{2}{*}{ Total aberrations } \\
\hline & & Chromatid type & Chromosome type & \\
\hline \multirow{4}{*}{48} & Control & $7.33 \pm 0.67$ & - & $7.33 \pm 0.67^{\mathrm{a}}(2.44)$ \\
\hline & Conditioning & $32.67 \pm 0.88$ & $3.00 \pm 0.58$ & $35.67 \pm 1.45^{\mathrm{b}}(11.89)$ \\
\hline & Challenging & $143.00 \pm 5.51$ & $14.33 \pm 2.03$ & $157.33 \pm 7.31^{\mathrm{c}}(52.44)$ \\
\hline & Combined & $106.67 \pm 1.86$ & $11.67 \pm 1.76$ & $118.33 \pm 2.96^{\mathrm{d}}(39.44)$ \\
\hline \multirow{4}{*}{72} & Control & $8.00 \pm 1.16$ & - & $8.00 \pm 1.16^{\mathrm{a}}(2.67)$ \\
\hline & Conditioning & $25.33 \pm 2.33$ & $1.33 \pm 0.33$ & $26.66 \pm 2.60^{\mathrm{b}}(8.89)$ \\
\hline & Challenging & $118.67 \pm 1.86$ & $12.00 \pm 1.53$ & $130.67 \pm 2.96^{\mathrm{e}}(43.56)$ \\
\hline & Combined & $84.00 \pm 3.79$ & $7.33 \pm 1.20$ & $91.33 \pm 4.98^{\mathrm{f}}(30.44)$ \\
\hline
\end{tabular}

Note: average data of 3 independent experiments; 3 animals per experiment were used; 100 cells per animal scored; and a total of 900 cells scored per dose. Values with same superscripts are not significantly different $(P>0.05)$, whereas values with different superscripts are significantly different $(P<0.05)$ from one another. Parentheses show the percentage of total aberrations.

TABLE 3: Frequency of chromosomal aberrations observed after conditioning, challenging, and combined treatments of MMS in EAC cells at $24 \mathrm{~h}, 48 \mathrm{~h}$, and $72 \mathrm{~h}$ recovery times.

\begin{tabular}{|c|c|c|c|c|}
\hline \multirow{2}{*}{ Recovery time (h) } & \multirow{2}{*}{ Treatment } & \multicolumn{2}{|c|}{ Chromosomal aberrations } & \multirow{2}{*}{ Total aberrations } \\
\hline & & Chromatid type & Chromosome type & \\
\hline \multirow{4}{*}{24} & Control & $7.67 \pm 0.67$ & - & $7.67 \pm 0.67^{\mathrm{a}}(2.56)$ \\
\hline & Conditioning & $49.00 \pm 4.58$ & $5.00 \pm 1.53$ & $54.00 \pm 4.62^{\mathrm{c}}(18.00)$ \\
\hline & Challenging & $217.33 \pm 5.36$ & $33.00 \pm 3.06$ & $250.33 \pm 7.88^{\mathrm{h}}(83.44)$ \\
\hline & Combined & $152.67 \pm 4.33$ & $21.00 \pm 2.08$ & $173.67 \pm 6.39^{f}(57.89)$ \\
\hline \multirow{4}{*}{48} & Control & $9.00 \pm 1.00$ & - & $9.00 \pm 1.00^{\mathrm{a}}(3.00)$ \\
\hline & Conditioning & $39.67 \pm 2.60$ & $3.00 \pm 0.58$ & $42.67 \pm 2.40^{\mathrm{bc}}(14.22)$ \\
\hline & Challenging & $172.00 \pm 2.00$ & $23.00 \pm 1.15$ & $195 \pm 3.06^{\mathrm{g}}(65.00)$ \\
\hline & Combined & $119.00 \pm 6.43$ & $13.00 \pm 1.53$ & $132 \pm 7.09^{\mathrm{e}}(44.00)$ \\
\hline \multirow{4}{*}{72} & Control & $8.00 \pm 1.53$ & - & $8.00 \pm 1.53^{\mathrm{a}}(2.67)$ \\
\hline & Conditioning & $34.67 \pm 0.88$ & $2.67 \pm 0.33$ & $37.33 \pm 0.67^{\mathrm{b}}(12.44)$ \\
\hline & Challenging & $120.67 \pm 4.41$ & $12.67 \pm 1.86$ & $133.33 \pm 2.91^{\mathrm{e}}(44.44)$ \\
\hline & Combined & $69.00 \pm 2.89$ & $9.67 \pm 1.46$ & $78.67 \pm 3.93^{\mathrm{d}}(26.22)$ \\
\hline
\end{tabular}

For explanations, see Table 2.

using mouse, and Harish et al. [19] using human lymphocytes have shown that MMS is more potent inducer of aberrations than EMS and concluded that methylating agents are strong inducers of chromosomal aberrations compared to ethylating agents in different test systems.

In order to understand the peak activity of adaptive response, we have earlier tested different time lags between conditioning and challenging doses in mouse and concluded that the reduction in the number of aberrations is a consequence of high activity of repair enzymes in the cells that were more adaptive for the $8 \mathrm{~h}$ time lag than others [29]. The same time lag was employed in the present investigations. Pretreatment of low dose of EMS or MMS and then treated with high dose of the same agent after $8 \mathrm{~h}$ time lag resulted in significantly reduced frequency of chromosomal aberrations in EAC cell $(P<0.05)$. These results confirm the earlier observations of the authors [29]. This is the first report on the induction of adaptive response using chemical agents in in vivo cancer system using clastogenic end point, as far as our knowledge goes.
The preliminary toxicity studies in EAC cells with MMS have revealed that there is dose effect relationship. Even though the tested lowest dose of $25 \mathrm{mg} / \mathrm{kg}$ body weight could not induce significant chromosomal aberration compared to controls, the doses of $50 \mathrm{mg} / \mathrm{kg}$ body weight and above produced significant aberrations [61]. Similarly, in case of EMS, doses above $80 \mathrm{mg} / \mathrm{kg}$ body weight yielded significant aberrations (unpublished data).

The present in vivo results of EAC cells are consistent with those of Lee et al. [40], where they have demonstrated the presence of adaptive response in in vitro sarcoma 180 cells primed with low dose of EMS using survival of the cells as the end point. Similarly employing radiations (low dose of $0.05 \mathrm{cGy} /$ day for 4-day period) Boothman et al. [33] showed adaptive response in human malignant melanoma cells.

Shadley et al. [66] suggested that the response ceases after the third mitosis of adapted cells, due to dilution of the repair system as the cells divide into subsequent cell cycles. Similarly, it was earlier shown [29-32] that, at $72 \mathrm{~h} \mathrm{RT,} \mathrm{third}$ subsequent mitoses, the reduction in frequency of chromatid 
TABLE 4: Percent reduction of chromosomal aberrations in EAC cells after combined treatment of EMS or MMS at different recovery times.

\begin{tabular}{lcccc}
\hline $\begin{array}{l}\text { Alkylating } \\
\text { agent }\end{array}$ & $\begin{array}{c}\text { Recovery } \\
\text { time (h) }\end{array}$ & $\begin{array}{c}\text { Additive effect } \\
\text { (conditioning + challenging } \\
\text { dose) } \\
(\%)\end{array}$ & $\begin{array}{c}\text { Combined effect } \\
\text { treatment of conditioning and } \\
\text { challenging dose together) } \\
(\%)\end{array}$ \\
\hline \multirow{2}{*}{ MMS } & 24 & 101.44 & 57.89 & $\begin{array}{c}C \\
\text { Reduction } \\
(\%)\end{array}$ \\
& 48 & 79.22 & 44.00 & $42.93^{\mathrm{b}}$ \\
EMS & 72 & 56.88 & 26.22 & $44.46^{\mathrm{b}}$ \\
& 24 & 74.78 & 47.44 & $33.91^{\mathrm{c}}$ \\
\hline
\end{tabular}

Note: values with the same superscripts are not significantly different $(P>0.05)$, whereas values with different superscripts are significantly different $(P<0.05)$ from one another. Percentage of reduction was calculated by using formula $C=(B / A * 100)-100$.

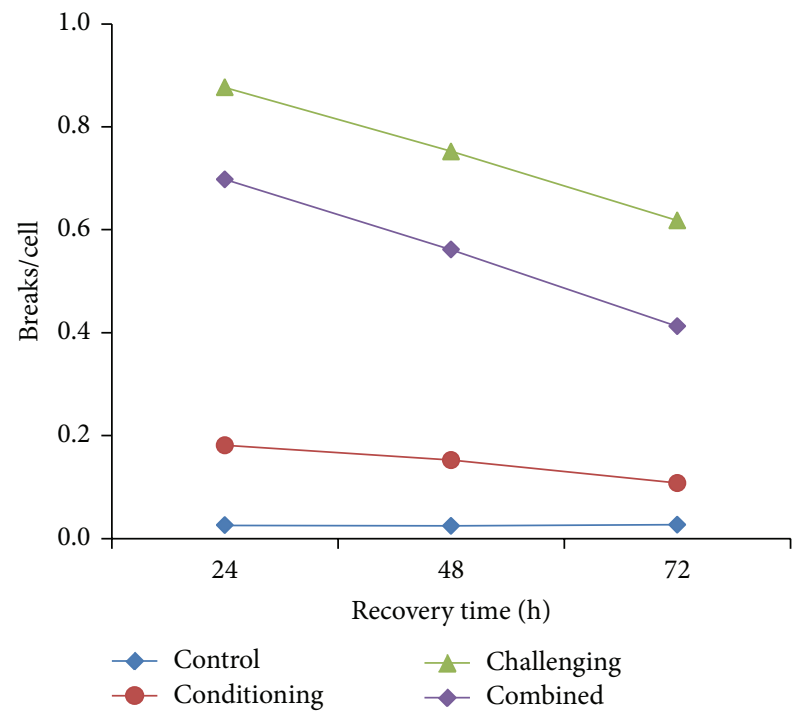

FIGURE 1: Yield of breaks/cell after different treatment schedules of EMS.

aberration is very minimal in normal mouse bone marrow cells. Another point they also noted in the same system is that the lowest aberration frequency was observed at $72 \mathrm{~h}$ RT compared to $24 \mathrm{~h}$ and $48 \mathrm{~h}$ RTs. In the present investigation, it is observed that, at $72 \mathrm{~h} \mathrm{RT}$ in EAC cells, that is, cancerous cell, there is reduction in chromatid aberrations and it can also be noted that the lowest aberrations were seen at $72 \mathrm{~h}$ than at 24 and $48 \mathrm{~h}$ RT (Tables 1-3). This agrees with earlier reports where it has been amply proven that the decrease in aberration frequency with increasing culturing time reflects a mechanism of mitotic selection of aberration bearing cells [67]. When the data of normal and cancer cells are taken together with respect to the adaptive response and different recovery times, there is not much difference.

The decline in aberration frequency was evident in that it produced $57.89 \%$ when the animals were treated with both conditioning and challenging doses separated by $8 \mathrm{~h}$ (combined treatment) compared to $101.44 \%$ of additive effect of both the conditioning and challenging doses of MMS treated

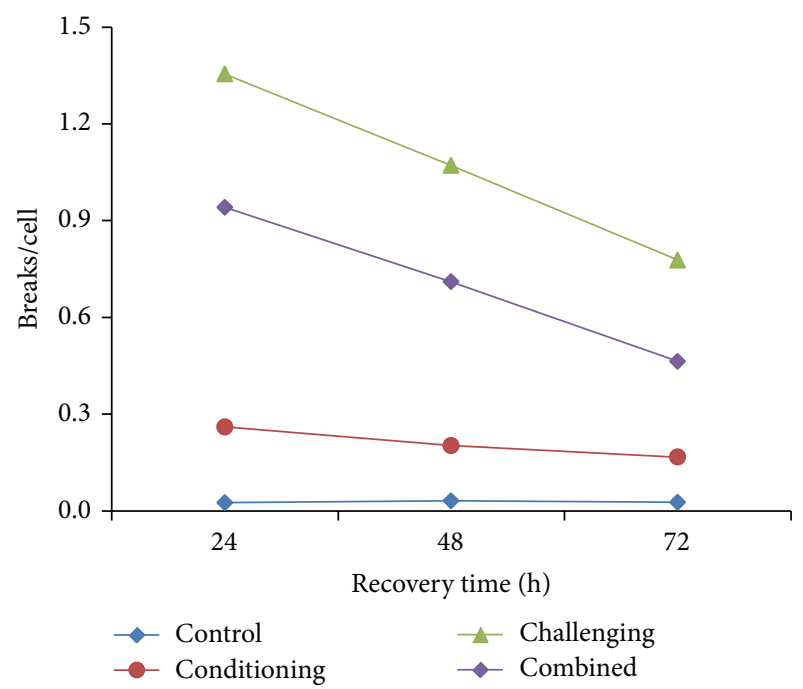

FIGURE 2: Yield of breaks/cell after different treatment schedules of MMS.

at $24 \mathrm{~h}$ RT (Table 4). This reduction in induced aberration frequencies by the combined treatment of MMS or EMS was observed over the whole range of RTs tested (Table 4). These results suggest that the conditioning doses of MMS or EMS given $8 \mathrm{~h}$ before the challenging treatment might have induced protection against the damaging effects of the challenging dose of respective agents in the in vivo EAC cells. It is pertinent to mention here that EMS or MMS induces adaptive response by significantly repairing the damaged meiotic cells of $P$. pictus and bone marrow cells of mouse [24-32]. Thus it appears from the results that both categories of alkylating agents, ethylating EMS and methylating MMS, possess the ability to induce an adaptive response in in vivo system of EAC cells similar to normal cells. However, low dose of MMS is more effective in conditioning the mitotic cells of EAC than EMS. Thus, maximum reduction from $56.89 \%$ to $26.22 \%$ (about $53.91 \%$ ) can be seen in combined treated EAC cells by MMS at $72 \mathrm{~h} \mathrm{RT}$, whereas, in the case of EMS, the maximum reduction of aberrations is from $52.44 \%$ 
to $30.44 \%$ (about $41.94 \%$ ) at the same recovery time (Table 4 ). It appears that both chemicals induce adaptive response, but the methylating agent is a more effective inducer. Similar results were also observed in the induction of adaptive response in in vivo mouse test system at $8 \mathrm{~h}$ time lag [2932]. These results are supported by the finding of Olsson and Lindahl [68], where they have demonstrated that the Ada coded methyltransferase transfers the ethyl group $\mathrm{O}^{6}$ ethylguanine at a rate of 10 times less than that for the methyl transfer. These are further strengthened from the evidences presented by earlier researchers $[69,70]$. In in vivo wildtype $E$. coli, the adaptive response began to contribute to $\mathrm{O}^{6}$-methylguanine repair about one hour after alkylation, which is the time required for full induction of the Ada DNA methyltransferase. In contrast, the adaptive response did not play such a large role in the repair of $\mathrm{O}^{6}$-ethylguanine and $\mathrm{O}^{4}$ ethylthymine, presumably because DNA ethylation damage is a poor inducer of the adaptive response. These observations including the present in vivo EAC cells studies underline the importance of ethylation and methylation in the analysis of adaptive response and hence further work is required in this direction.

In summary, based on the present results and our previous studies it can be concluded that both EMS and MMS induce adaptive response not only in normal cells but also in cancerous cells. Further, there is also indication of the existence of differential adaptive response to chromosome damage induced by ethylating and methylating agents in in vivo EAC cells, similar to that described in normal biological systems. Taking into account that chemotherapy with alkylating drugs is based on their genotoxic and clastogenic efficiency to interrupt replication and tumor cell division, what prospects are for clinical implications of the adaptive response in such cells? Probably, differences between clastogenic effects of methylating and ethylating agents and their capacity to trigger the protective mechanism against chromosomal aberrations in tumor cells might be important for elaboration of chemotherapy approaches. But, in the context of clinical applications, the fact is more interesting that inducible $\mathrm{O}^{6}$-methylguanine-DNA methyltransferase has been recognized as a potential target for cross-linking agents causing enzymatic depletion to increase susceptibility of tumor cells to action of other alkylating drugs $[71,72]$.

\section{Conflict of Interests}

The authors declare that there is no conflict of interests regarding the publication of this paper.

\section{Acknowledgments}

The authors wish to express their gratitude to the Director of Post-Graduate Centre, University of Mysore, Hemagangotri, for providing facilities and to Professor K. K. Vijayalakshmi, Department of Applied Zoology, Mangalore University, Mangalore, for providing the Ehrlich ascites carcinoma cells. The authors also thank Professor B. S. Vishwanath (Department of Biochemistry) and Professor H. N. Yajurvedi (Department of Zoology), University of Mysore, Mysore, for their kind help during the course of this work. The authors also thank an unknown referee for the comments by which it was possible for them to strengthen the paper.

\section{References}

[1] L. Samson and J. Cairns, "A new pathway for DNA repair in Escherichia coli," Nature, vol. 267, no. 5608, pp. 281-283, 1977.

[2] P. Jeggo, "Isolation and characterization of Escherichia coli K12 mutants unable to induce the adaptive response to simple alkylating agents," Journal of Bacteriology, vol. 139, no. 3, pp. 783-791, 1979.

[3] B. Kaina, "Enhanced survival and reduced mutation and aberration frequencies induced in V79 Chinese hamster cells preexposed to low levels of methylating agents," Mutation Research, vol. 93, no. 1, pp. 195-211, 1982.

[4] C. T. Hadden, R. S. Foote, and S. Mira, "Adaptive response of Bacillus subtilis to N-methyl-N'-nitro-N-nitrosoguanidine," Journal of Bacteriology, vol. 153, no. 2, pp. 756-762, 1983.

[5] A. Ather, Z. Ahmed, and S. Riazuddin, "Adaptive response or Micrococcus luteus to alkylating chemlcals," Nucleic Acids Research, vol. 12, no. 4, pp. 2111-2126, 1984.

[6] T. Ikushima, "Chromosomal responses to ionizing radiation reminiscent of an adaptive response in cultured Chinese hamster cells," Mutation Research, vol. 180, no. 2, pp. 215-221, 1987.

[7] K. A. Vallis and C. R. Wolf, "Relationship between the adaptive response to oxidants and stable menadione-resistance in Chinese hamster ovary cell lines," Carcinogenesis, vol. 17, no. 4, pp. 649-654, 1996.

[8] B. Kaya, A. Creus, A. Velázquez, A. Yanikoğlu, and R. Marcos, "Induction of an adaptive response in Drosophila imaginal disc cells exposed in vivo to low doses of alkylating agents," Mutagenesis, vol. 15, no. 4, pp. 337-340, 2000.

[9] N. Savina, O. Dalivelya, and T. Kuzhir, "Adaptive response to alkylating agents in the Drosophila sex-linked recessive lethal assay," Mutation Research-Genetic Toxicology and Environmental Mutagenesis, vol. 535, no. 2, pp. 195-204, 2003.

[10] S. B. Schwarz, P. M. Schaffer, U. Kulka, B. Ertl-Wagner, R. Hell, and M. Schaffer, "The effect of radio-adaptive doses on HT29 and GM637 cells," Radiation Oncology, vol. 3, no. 1, p. 12, 2008.

[11] H. Yang, S. E. Lee, G. Kim, H. R. Park, and Y. S. Park, "Hemeoxygenase-1 mediates an adaptive response to spermidine-induced cell death in human endothelial cells," Oxidative Medicine and Cellular Longevity, vol. 2013, Article ID 238734, 7 pages, 2013.

[12] G. Olivieri, J. Bodycote, and S. Wolff, "Adaptive response of human lymphocytes to low concentrations of radioactive thymidine," Science, vol. 223, no. 4636, pp. 594-597, 1984.

[13] J. D. Shadley and S. Wolff, "Very low doses of X-rays can cause human lymphocytes to become less susceptible to ionizing radiation," Mutagenesis, vol. 2, no. 2, pp. 95-96, 1987.

[14] K. Sankaranarayanan, V. A. Duyn, M. J. Loos, and A. T. Natarajan, "Adaptive response of human lymphocytes to low-level radiation from radioisotopes or X-rays," Mutation Research, vol. 211, no. 1, pp. 7-12, 1989.

[15] G. Olivieri and A. Bosi, "Possible causes of the adaptive response in human lymphocytes," in Chromosomal Aberrations: Basic and Applied Aspects, G. Obe and A. T. Natarajan, Eds., pp. 130-139, Springer, Berlin, Germany, 1990. 
[16] E. Madrigal-Bujaidar, M. Cassani, S. Martinez, and T. Morales, "Adaptive response induced by mitomycin $\mathrm{C}$ measuring the frequency of SCEs in human lymphocyte cultures," Mutation Research-Genetic Toxicology, vol. 322, no. 4, pp. 301-305, 1994.

[17] L. Zhang, "Cytogenetic adaptive response induced by preexposure in human lymphocytes and marrow cells of mice," Mutation Research, vol. 334, no. 1, pp. 33-37, 1995.

[18] T. Nikolova and E. Hüttner, "Adaptive and synergistic effects of a low-dose ENU pretreatment on the frequency of chromosomal aberrations induced by a challenge dose of ENU in human peripheral blood lymphocytes in vitro," Mutation ResearchFundamental and Molecular Mechanisms of Mutagenesis, vol. 357, no. 1-2, pp. 131-141, 1996.

[19] S. K. Harish, K. P. Guruprasad, R. Mahmood, V. Vasudev, K. R. Manjunath, and G. K. Chethan, "Adaptive response to low dose of EMS or MMS in human peripheral blood lymphocytes," Indian Journal of Experimental Biology, vol. 36, no. 11, pp. 11471150, 1998.

[20] K. Schlade-Bartusiak, A. Stembalska-Kozlowska, M. Bernady, M. Kudyba, and M. Sasiadek, "Analysis of adaptive response to bleomycin and mitomycin C," Mutation Research-Genetic Toxicology and Environmental Mutagenesis, vol. 513, no. 1-2, pp. 75-81, 2001.

[21] R. Rieger, A. Michaelis, and H. Nicoloff, "Inducible repair processes in plant root tip meristems? "Below additivity effects" of unequally fractionated clastogen concentrations," Biologisches Zentralblatt, vol. 101, pp. 125-138, 1982.

[22] R. Rieger, A. Michaelis, and S. Takehisa, "An adaptive response of plant meristem cells in vivo protection against induction of chromatid aberrations," in Chromosomal Aberrations: Basic and Applied Aspects, G. Obe and A. T. Natarajan, Eds., pp. 163-179, Springer, Berlin, Germany, 1990.

[23] P. Baranczewski, P. Nehls, R. Rieger, M. F. . Rajewsky, and I. Schubert, "Removal of $\mathrm{O}^{6}$-methyl guanine from plant DNA in vivo is accelerated under conditions of clastogenic adaptation," Environmental and Molecular Mutagenesis, vol. 29, no. 4, pp. 400-405, 1997.

[24] R. Mahmood and V. Vasudev, "Inducible protective processes in animal systems: I.Clastogenic adaptation triggered by ethyl methanesulfonate (EMS) in Poecilocerus pictus," Biologisches Zentralblatt, vol. 109, pp. 41-43, 1990.

[25] R. Mahmood and V. Vasudev, "Inducible protective processes in animal systems. III. Adaptive response of meiotic cells of the grasshopper, Poecilocerus pictus, to a low dose of ethyl methanesulfonate," Mutation Research-Mutation Research Letters, vol. 283, no. 4, pp. 243-247, 1992.

[26] V. Vasudev, K. P. Guruprasad, S. K. Haris h, and R. Venu, "Inducible protective processes in animal systems: VII. Involvement of poly (ADP- ribose) polymerase (PARP) in EMS induced adaptive response in grasshopper Poecilocerus pictus meiotic cells," Proceedings of the Academy of Environmental Biology, vol. 8, pp. 259-266, 1999.

[27] K. P. Guruprasad and V. Vasudev, "Inducible protective processes in animal systems. IX. Potentiality of adaptive response by nicotinamide in MMS adapted meiotic cells of grasshopper Poecilocerus pictus," Biologia, vol. 56, no. 6, pp. 649-654, 2001.

[28] R. Mahmood and V. Vasudev, "Inducible protective processes in animal systems: IV. Adaptation of mouse bone marrow cells to a low dose of ethyl methanesulfonate," Mutagenesis, vol. 8, no. 1, pp. 83-86, 1993.

[29] R. Mahmood, V. Vasudev, S. K. Harish, and K. P. Guruprasad, "Inducible protective processes in animal systems: adaptive response to a low dose of methyl methanesulfonate in mouse bone marrow cells," Indian Journal of Experimental Biology, vol. 34, no. 6, pp. 502-507, 1996.

[30] S. K. Harish, K. P. Guruprasad, R. Mahmood, and V. Vasudev, "Inducible protective processes in animal systems VI. Crossadaptation and the influence of caffeine on the adaptive response in bone marrow cells of mouse," Mutagenesis, vol. 15, no. 3, pp. 271-276, 2000.

[31] K. P. Guruprasad and V. Vasudev, "Inducible protective processes in animal systems: VIII. Enhancement of adaptive response by nicotinamide," Mutagenesis, vol. 16, no. 3, pp. 257263, 2001.

[32] K. P. Guruprasad, V. Vasudev, M. N. Anilkumar, and S. A. Chethan, "Inducible protective processes in animal systems. X. Influence of nicotinamide in methyl methanesulfonate-adapted mouse bone marrow cells," Mutagenesis, vol. 17, no. 1, pp. 1-8, 2002.

[33] D. A. Boothman, M. Meyers, E. Odegaard, and M. Wang, "Altered G1 checkpoint control determines adaptive survival responses to ionizing radiation," Mutation ResearchFundamental and Molecular Mechanisms of Mutagenesis, vol. 358, no. 2, pp. 143-153, 1996.

[34] I. V. Filippovich, N. I. Sorokina, N. Robillard, A. Lisbona, and J. F. Chatal, "Radiation-induced apoptosis in human tumor cell lines: adaptive response and split-dose effect," International Journal of Cancer, vol. 77, pp. 76-81, 1998.

[35] H. Seo, H. Chung, Y. Lee, S. Bae, S. Lee, and Y. Lee, “p27Cip/Kip is involved in Hsp25 or inducible Hsp70 mediated adaptive response by low dose radiation," Journal of Radiation Research, vol. 47, no. 1, pp. 83-90, 2006.

[36] H. Matsumoto, A. Takahashi, and T. Ohnishi, "Nitric oxide radicals choreograph a radioadaptive response," Cancer Research, vol. 67, no. 18, pp. 8574-8579, 2007.

[37] H. Klammer, M. Kadhim, and G. Iliakis, "Evidence of an adaptive response targeting DNA nonhomologous end joining and its transmission to bystander cells," Cancer Research, vol. 70, no. 21, pp. 8498-8506, 2010.

[38] E. L. Anuszewska and J. H. Koziorowska, "Capability of adriamycin and busulfan to induce adaptive response in vitro," Archivum Immunologiae et Therapiae Experimentalis, vol. 47, no. 1, pp. 51-54, 1999.

[39] J. H. Lee, K. S. Oh, D. W. Lee, E. J. Shin, and K. I. Um, “The effect of pretreatment of with various mutagens on glycoconjugates of plasma membrane in HeLa cells," Environmental Mutagens and Carcinogens, vol. 18, pp. 116-122, 1998.

[40] J. H. Lee, E. S. Choi, K. S. Oh, D. W. Lee, J. H. Chang, and K. I. Um, "Effect of low dose mutagens on adaptive response and plasma membrane glyconjugates in sarcoma 180 cells," Korean Journal of Biological Science, vol. 4, no. 3, pp. 293-297, 2000.

[41] S. H. Park, Y. Lee, K. Jeong, S. Y. Yoo, C. K. Cho, and Y. Lee, "Different induction of adaptive response to ionizing radiation in normal and neoplastic cells," Cell Biology and Toxicology, vol. 15, no. 2, pp. 111-119, 1999.

[42] M. Schaffer, S. B. Schwarz, U. Kulka, M. Busch, and E. Dühmke, "Adaptive doses of irradiation-an approach to a new therapy concept for bladder cancer?" Radiation and Environmental Biophysics, vol. 43, no. 4, pp. 271-276, 2004.

[43] H. Jiang, W. Li, X. Li, L. Cai, and G. Wang, "Low-dose radiation induces adaptive response in normal cells, but not in tumor cells: in vitro and in vivo studies," Journal of Radiation Research, vol. 49, no. 3, pp. 219-230, 2008. 
[44] M. B. Sowa, W. Goetz, J. E. Baulch, A. J. Lewis, and W. F. Morgan, "No evidence for a low linear energy transfer adaptive response in irradiated RKO cells," Radiation Protection Dosimetry, vol. 143, no. 2-4, Article ID ncq487, pp. 311-314, 2011.

[45] S. Wang, G. Jiang, H. Yu, X. Liu, and C. Xu, "Effect of lowdose $\mathrm{X}$-ray radiation on adaptive response in gastric cancer cell," Chinese-German Journal of Clinical Oncology, vol. 12, no. 4, pp. P171-P174, 2013.

[46] F. P. Evans, G. Breckon, and C. E. Ford, "An air drying method for meiotic preparation from mammalian testes," Cytogenetics, vol. 3, pp. 289-294, 1964.

[47] J. R. Savage, "Classification and relationships of induced chromosomal structural changes," Journal of Medical Genetics, vol. 13, no. 2, pp. 103-122, 1976.

[48] S. G. Chaney and A. Sancar, "DNA repair: enzymatic mechanisms and relevance to drug response," Journal of the National Cancer Institute, vol. 88, no. 19, pp. 1346-1360, 1996.

[49] L. H. Hurley, "DNA and its associated processes as targets for cancer therapy," Nature Reviews Cancer, vol. 2, no. 3, pp. 188200, 2002.

[50] J. H. Baek, M. Han, S. Y. Lee, and J. Yoo, “Transcriptome and proteome analyses of adaptive responses to methyl methanesulfonate in Escherichia coli K-12 and ada mutant strains," BMC Microbiology, vol. 9, pp. 186-198, 2009.

[51] B. Kaina, M. Christmann, S. Naumann, and W. P. Roos, "MGMT: key node in the battle against genotoxicity, carcinogenicity and apoptosis induced by alkylating agents," DNA Repair, vol. 6, no. 8, pp. 1079-1099, 2007.

[52] N. Kondo, A. Takahashi, K. Ono, and T. Ohnishi, "DNA damage induced by alkylating agents and repair pathways," Journal of Nucleic Acids, vol. 2010, Article ID 543531, 7 pages, 2010.

[53] G. A. Sega, "A review of the genetic effects of ethyl methanesulfonate," Mutation Research, vol. 134, no. 2-3, pp. 113-142, 1984.

[54] J. K. Lim and L. A. Snyder, "The mutagenic effects of two monofunctional alkylating chemicals of mature spermatozoa of Drosophila," Mutation Research-Fundamental and Molecular Mechanisms of Mutagenesis, vol. 6, no. 1, pp. 129-137, 1968.

[55] E. Vogel and A. T. Natarajan, "The relation between reaction kinetics and mutagenic action of mono-functional alkylating agents in higher eukaryotic systems. I. Recessive lethal mutations and translocations in Drosophila," Mutation Research, vol. 62, no. 1, pp. 51-100, 1979.

[56] E. Vogel and A. T. Natarajan, "The relation between reaction kinetics and mutagenic action of mono-functional alkylating agents in higher eukaryotic systems. II. Total and partial sexchromosome loss in Drosophila," Mutation Research, vol. 62, no. 1, pp. 101-123, 1979.

[57] J. B. Boyd and R. B. Setlow, "Characterization of postreplication repair in mutagen sensitive strains of Drosophila melanogaster," Genetics, vol. 84, no. 3, pp. 507-526, 1976.

[58] B. Lambert, M. Sten, D. Hellgren, and D. Francesconi, "Different SCE-inducing effects of HN2 and MMS in early and late G1 in human lymphocytes," Mutation Research Letters, vol. 139, no. 2, pp. 71-77, 1984 .

[59] M. M. Moore, K. Harrington-Brock, C. L. Doerr, and K. L. Dearfield, "Differential mutant quantitation at the mouse lymphoma tk and CHO hgprt loci," Mutagenesis, vol. 4, no. 5, pp. 394-403, 1989.

[60] I. Decordier, E. Cundari, and M. Kirsch-Volders, "Influence of caspase activity on micronuclei detection: a possible role for caspase-3 in micronucleation," Mutagenesis, vol. 20, no. 3, pp. 173-179, 2005.
[61] T. Nikolova, M. Ensminger, M. Löbrich, and B. Kaina, "Homologous recombination protects mammalian cells from replication-associated DNA double-strand breaks arising in response to methyl methanesulfonate," DNA Repair, vol. 9, no. 10, pp. 1050-1063, 2010.

[62] P. V. Mahadimane and V. Vasudev, "Effect of methyl methane sulfonate on Ehrlich Ascites Carcinoma cells: dose effect relationships," International Journal of Lifescience and Pharma Research, vol. 3, pp. 22-31, 2013.

[63] R. Lettré, N. Paweletz, D. Werner, and C. Granzow, "Sublines of the ehrlich-lettré mouse ascites tumour a new tool for experimental cell research," Die Naturwissenschaften, vol. 59, no. 2, pp. 59-63, 1972.

[64] R. N. Rao and A. T. Natarajan, "Somatic association in relation to chemically induced chromosome aberration in Vicia faba," Genetics, vol. 57, pp. 821-835, 1967.

[65] E. Vogel and A. T. Natarajan, "The relation between reaction kinetics and mutagenic action of monofunctional alkylating agents in higher eukaryotic systems," in Chemical Mutagens: Principles and Methods for Their Detection, F. J. de Serres and A. Hollaender, Eds., vol. 7, pp. 295-336, Plenum Press, New York, NY, USA, 1982.

[66] J. D. Shadley, V. Afzal, and S. Wolff, "Characterization of the adaptive response to ionizing radiation induced by low doses of $\mathrm{X}$ rays to human lymphocytes," Radiation Research, vol. 111, no. 3, pp. 511-517, 1987.

[67] G. Obe and B. Beak, "Human leukocyte test system," in Chemical Mutagens: Principles and Methods for Their Detection, F. J. de Serres and A. Hollaender, Eds., vol. 7, pp. 337-400, Plenum Press, New York, NY, USA, 1982.

[68] M. Olsson and T. Lindahl, "Repair of alkylated DNA in Escherichia coli. Methyl group transfer from $\mathrm{O}^{6}$-methylguanine to a protein cysteine residue," Journal of Biological Chemistry, vol. 255, no. 22, pp. 10569-10571, 1980.

[69] M. Otsuka, Y. Nakabeppu, and M. Sekiguchi, "Ability of various alkylating agents to induce adaptive and SOS responses: a study with lacZ fusion," Mutation Research, vol. 146, no. 2, pp. 149-154, 1985.

[70] L. Samson, J. Thomale, and M. F. Rajewsky, "Alternative pathways for the in vivo repair of $\mathrm{O}^{6}$-alkylguanine and $\mathrm{O} 4$ alkylthymine in Escherichia coli: the adaptive response and nucleotide excision repair," EMBO Journal, vol. 7, no. 7, pp. 22612267, 1988.

[71] R. O. Pieper, B. W. Futscher, Q. Dong, and L. C. Erickson, "Effects of streptozotocin/bis-chloroethylnitrosourea combination therapy on $\mathrm{O}^{6}$-methylguanine DNA methyltransferase activity and mRNA levels in HT-29 cells in vitro," Cancer Research, vol. 51, no. 6, pp. 1581-1585, 1991.

[72] P. E. Gonzaga, P. M. Potter, T. Niu et al., "Identification of the cross-link between human $\mathrm{O}^{6}$-methylguanine-DNA methyltransferase and chloroethylnitrosourea-treated DNA," Cancer Research, vol. 52, no. 21, pp. 6052-6058, 1992. 


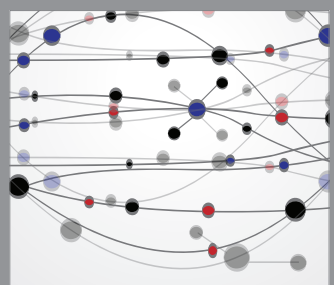

The Scientific World Journal
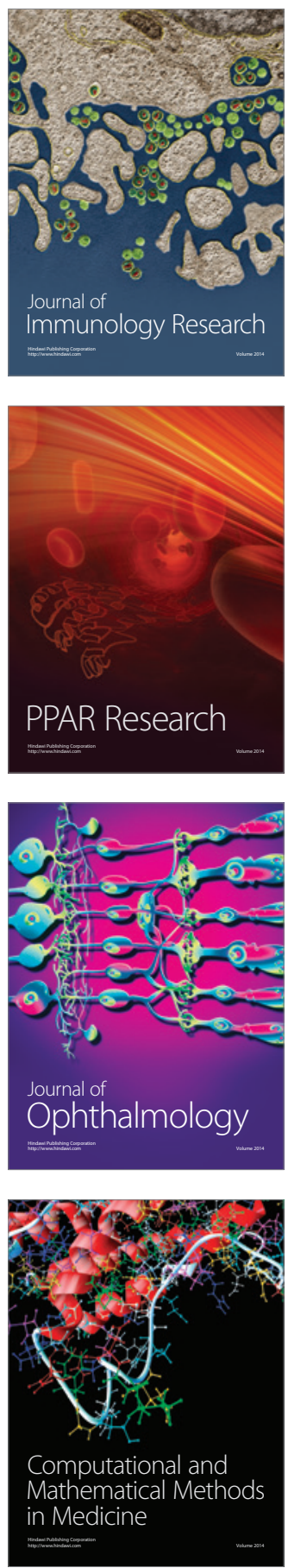

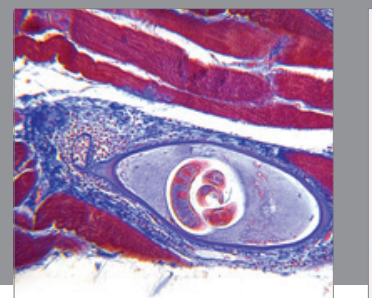

Gastroenterology

Research and Practice
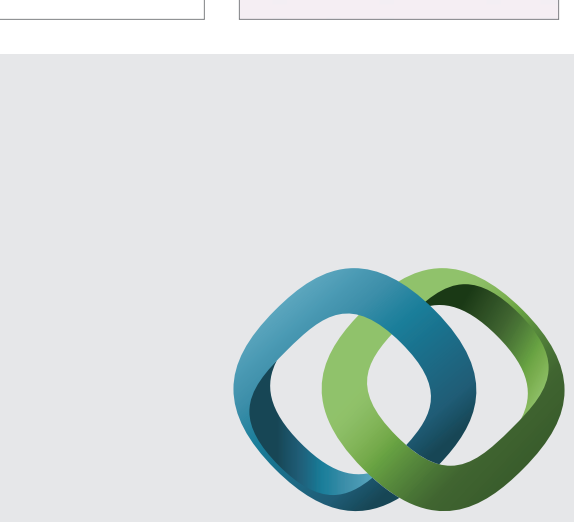

\section{Hindawi}

Submit your manuscripts at

http://www.hindawi.com
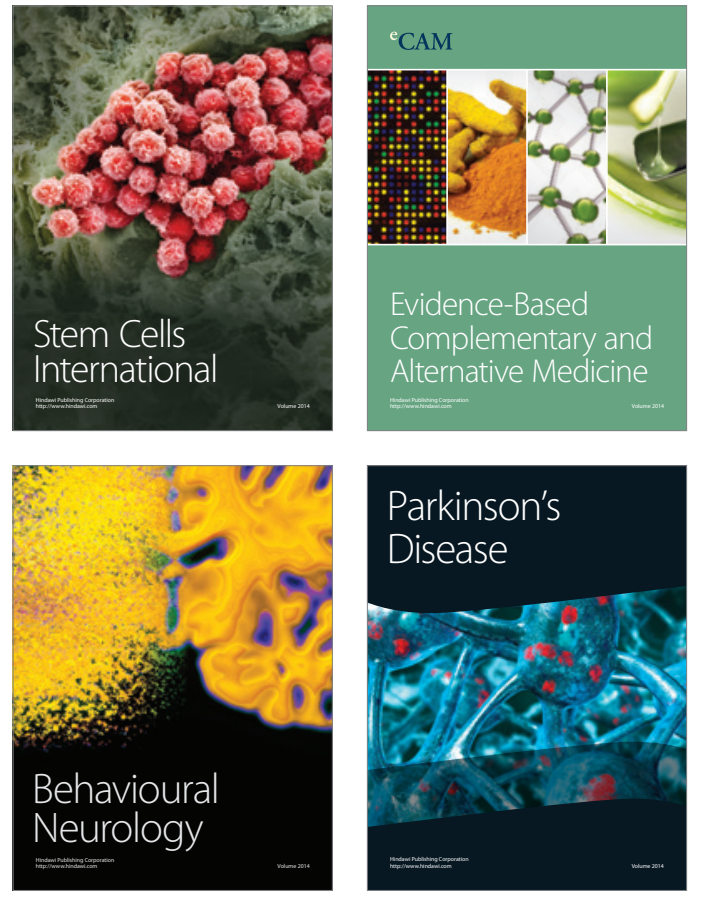
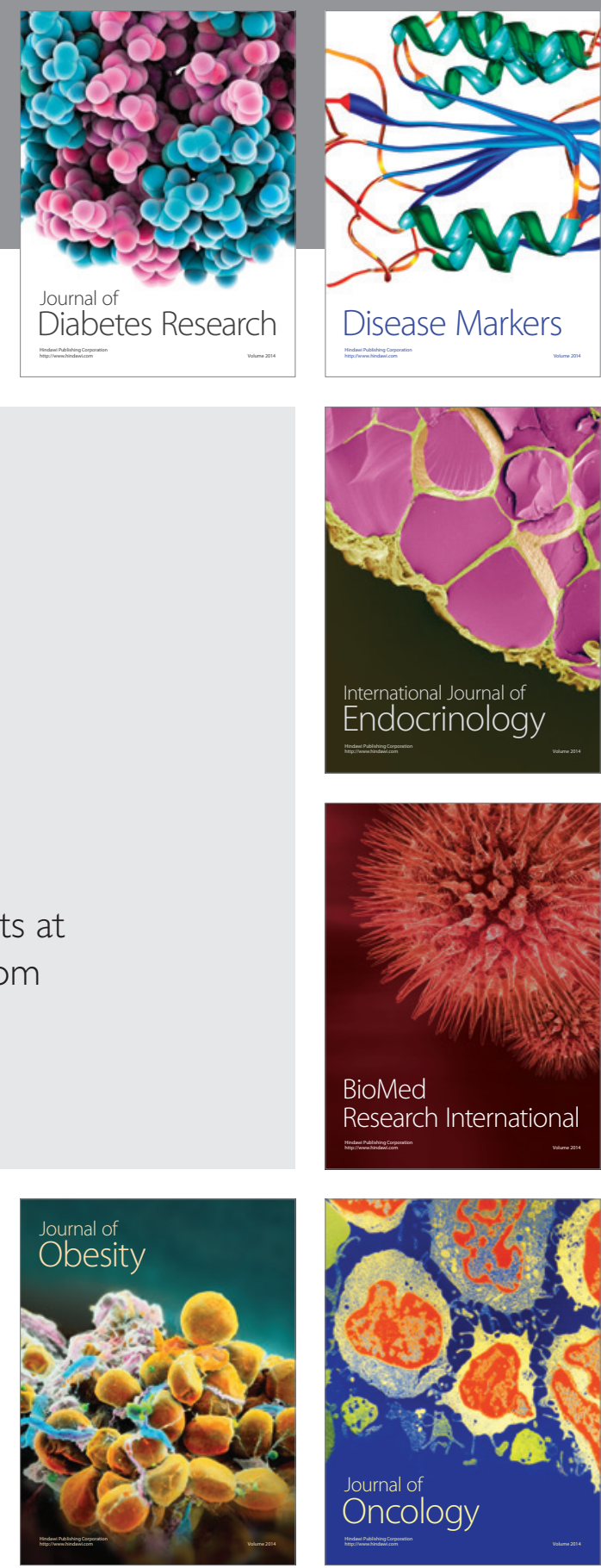

Disease Markers
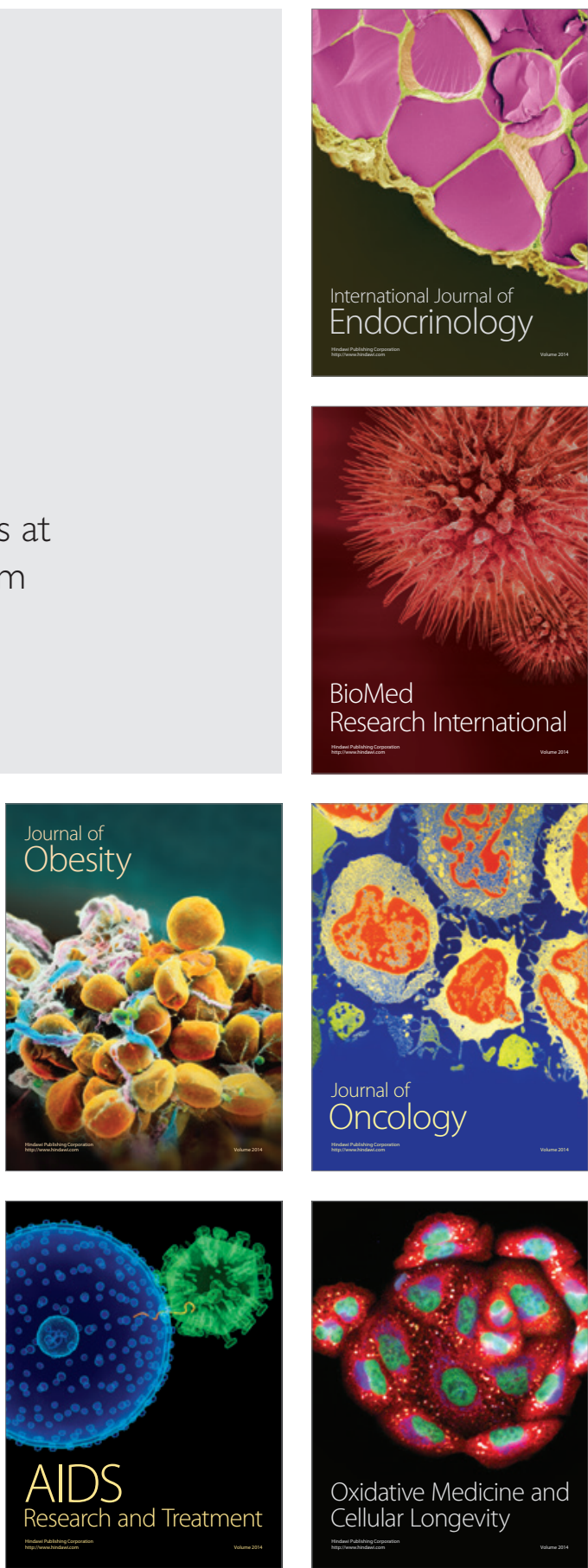